\title{
16. Water Flows and the Dynamics of Desert Vegetation Stripes
}

\author{
A.F. Cornet, C. Montana, J.P. Delhoume, \\ and J. Lopez-Portillo
}

\section{Introduction}

Around 1950, the development of aerial surveys showed the presence, in the arid and semiarid zones of Africa, of particular vegetation patterns, corresponding to plant communities established in parallel stripes, alternating with unvegetated zones. Such landscapes consist of a mosaic of bare areas and vegetated stripes, the major axes of which are always perpendicular to the slope. These striped vegetation patterns have subsequently been reported in many parts of the arid and semiarid regions of the world.

Many studies describe the structure and composition of these stripes and propose hypotheses for their establishment and origin (Worral 1959, Slatyer 1961, Litchfield and Mabbutt 1962, Boaler and Hodge 1964, Hemming 1965, White 1970, Wickens and Collier 1971, Boudet 1972, and Leprun 1979). The occurrence and formation of these patterns seem to originate under a combination of climatic, geomorphological, and edaphic condition: (1) an arid or semiarid climate with few, but high intensity, rains; (2) a gentle but regular slope $(0.25$ to $1.0 \%)$; (3) soils with low permeability and a relative abundance of fine particles, producing intense sheet runoff. A slow migration of stripes upslope has been noted by many authors (Worral 1959; Boaler and Hodge 1964; White 1970). It has been suggested that this vegetation pattern originates either from the progressive degradation of a more or less uniform plant cover under a worsening climate or soil 
degradation (White 1971; Greig-Smith 1979), or from the evolution of previously bare zones (White 1971; Boudet 1972). Recent observations (Cornet et al. 1987; Mabbutt and Fanning 1987) show that the development of vegetation stripes seems a consequence of the evolution of land forms. Various studies have emphasized the importance of superficial water dynamics to justify the establishment and maintenance of such vegetation patterns (Slatyer 1961, Hemming 1965, White 1970, Leprun 1979, Mabbutt and Fanning 1987), but only Slatyer (1961) includes a quantitative study of the water balance.

An ecotone is a zone of transition between adjacent ecological systems or between landscape elements (Di Castri et al. 1988). Factors creating heterogeneous patterns of species distribution or vegetation structure within the landscape create ecotones. In this case, the vegetation response to water flows and water availability along a broad geomorphic boundary results in the development of smaller-scale boundaries or ecotones, which further modify movement of water. The upper part of each vegetation stripe constitutes an ecotone that exerts control over water flows across the landscape and in doing so influences patch functioning and pattern dynamics. The striped vegetation pattern constitutes a self-modifying system, which permits an understanding of the relationships between ecological processes and ecotonal structure across landscapes.

Following an initial description of this type of vegetation in the Mapimi Biosphere Reserve in the Chihuahuan desert of Mexico (Cornet et al. 1987) and a study carried out from 1982 to 1986 to consider the importance of the water balance on the dynamics of plant communities (Cornet et al. 1988), this chapter relates the main characteristics and the current knowledge on the Mapimi vegetation stripes, and the results of studies of water balance and vegetation change. The objectives are to demonstrate the effect of ecotones on ecological flows across this type of landscape and to examine implications for ecotone dynamics.

\section{The Mapimi Vegetation Stripes: An Overview}

The Mapimi Biosphere Reserve is located in the central part of the arid zone of Mexico, at an average elevation of $1100 \mathrm{~m}$. It forms part of the Chihuahuan desert (Schmidt 1979). The climate is highland tropical arid (Cornet 1987), with an annual rainfall of $264 \mathrm{~mm}$ and a variation coefficient of $42 \%$ (recorded in Ceballos, 1956-1983, the nearest weather station). Most rains occur during summer, and the rainfall from June to September is $71 \%$ of the total annual rainfall. The average minimum temperature of the coldest month (January) is $3.9^{\circ} \mathrm{C}$, and the average maximum temperature of the warmest month (June) is $36.1^{\circ} \mathrm{C}$.

The various soil types in the reserve are mainly differentiated by their parent materials and the manner in which they were deposited. Most subs- 
trates are alluvia and colluvia, which are distributed in the landscape according to geomorphology (Breimer 1987, Delhoume 1987). The higher elevations with steep slopes are characterized by lithosols (FAO/UNESCO 1974) and by regosols on stony colluvions. The lower pediments with genthe slopes have yermosols and xerosols on alluvions of fine to medium texture. In the lower plains, the soils originate from alluvions with fine texture and variable levels of salinity; these are gypsic yermosols of the saline or sodic phase.

The vegetation corresponds to the "matorral xerofilo" described by Rzedowski (1981) or the "Chihuahuan desert scrub" of Brown (1982); it includes various shrublands where Larrea tridentata is dominant, and grasslands with or without shrubs, where Hilaria mutica and Sporobolus airoides are the major constituents (Montana 1987).

The landscape unit delimited by Montana and Breimer (1987) as "sierras and bajadas," is an area of high hills and pediments. This area has an elevation between 1200 and $1500 \mathrm{~m}$ and is underlain by volcanic and sedimentary rocks, with a colluvial-alluvial cover of the aforementioned materials, which have spread over pediments. This landscape can be divided into four main subunits, the third one of which concerns us herein: (A) summit with rock outcrop vegetation; (B) higher pediments with microphyllous matorral; (C) Hilaria mutica grasslands in the lower parts (Fig. 16.1); and (D) striped-patterned vegetation, or vegetation arcs on the upslope part of lower pediments.

In the striped pattern of vegetation (Item D in the Preceding list), the dense vegetation stripes follow isohypses, their width varies from 20 to $70 \mathrm{~m}$, and their length from 100 to $300 \mathrm{~m}$. The broadest stripes are to be found in the lower parts of the toposequence, and the ratio of width of vegetated stripes to bare zones varies from 24 to $30 \%$. Within each stripe, a zonation that often includes five elements can be found. This zonation (Fig. 16.2) has been described by Cornet et al. (1987).

In Mapimi, the soil profiles in the bare area were found to be the same as those within the stripes, but small differences in the thickness of the horizons and in the organic matter content of the top soil layer were found (Delhoume 1987). Vegetation seems to be the major cause for changes in some analytical characteristics and physical properties of the topsoil because the periodic litter fall induces a higher organic matter content, which, with the increasing amount of roots, produces a fine, structured soil and a higher water permeability. These differences are restricted to the upper $30 \mathrm{~cm}$, below which the soil characteristics are identical to those of the bare areas.

White (1971) and Greig-Smith (1979) propose two ways in which striped vegetation could establish: (1) a more or less homogeneous, dense plant cover evolves into stripelike patches of dense vegetation cover with bare ground between the stripes, or (2) bare ground or reduced plant cover develops vegetation stripes along natural obstacles that stop water runoff. 

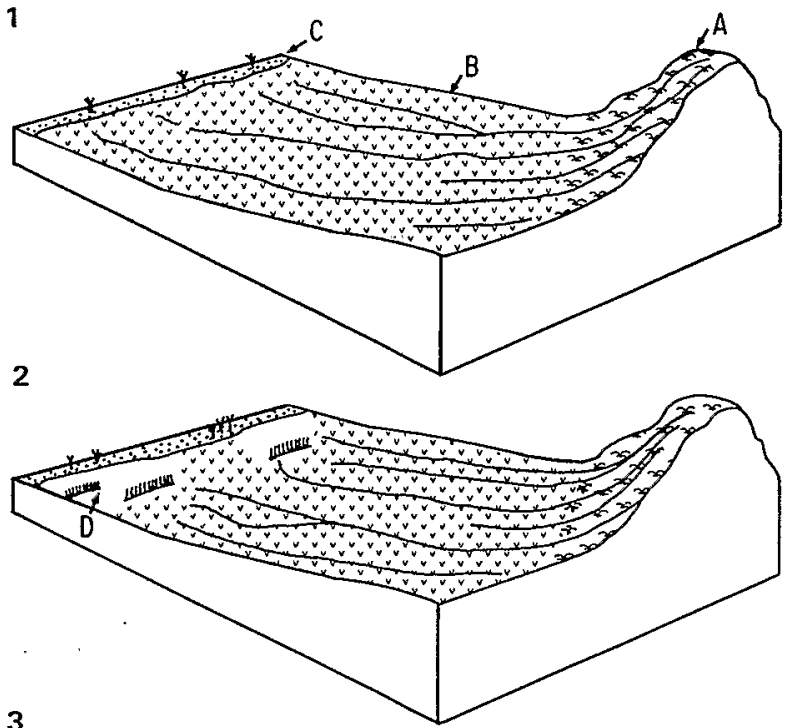

3

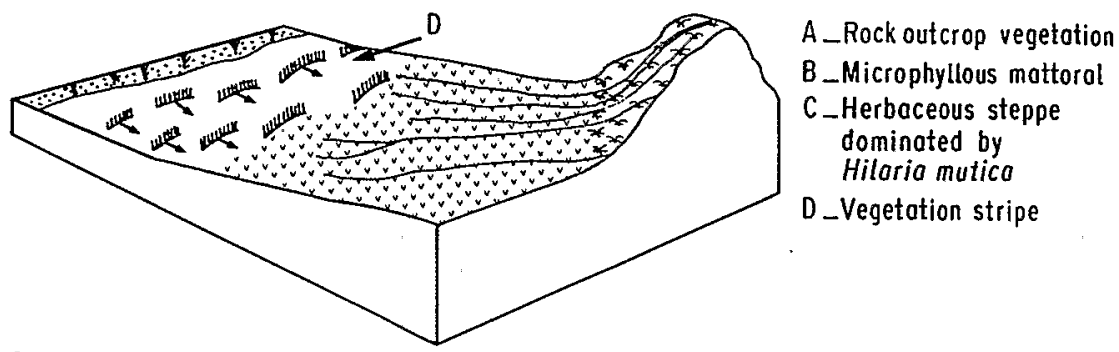

4

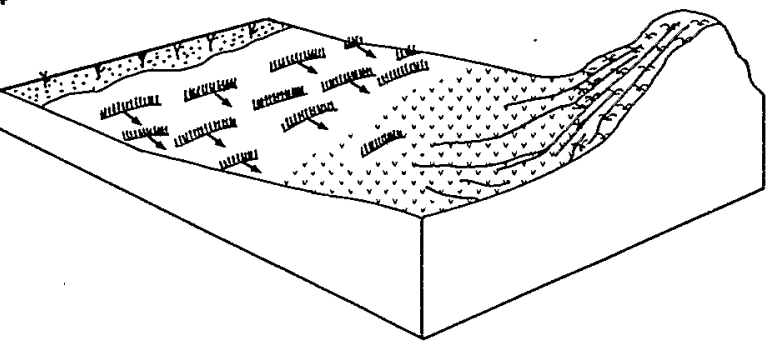

Figure 16.1. Sequence of landscape changes at the limit between the microphyllous matorral dominated by Larrea tridentata and the herbaceous steppe dominated by Hilaria mutica. (1) Uphill soils are eroded and attenuate the gentle slope (2) causing a change from gully-type water flow to a sheet-flow water circulation. The plants growing along the drainage axes build up as dense clumps, and water used by these highly demanding species (e.g., Flourensia cernua and Prospis glandulosa) is obtained from run-in water, which is collected in the bare areas and stored in the soil below these clumps (2-4). 
Bicers pulchellus Boulelowa barbetio Sida leprosa.

Hoffmanseggia densillara

Sphoeralcom angustifoli

Hiloria mulion

Nhourensia cem

Vifuierd 29.

Aloysia grolissima

Chtoris virtata

Panicum tallit

Lippis graweolens

Acocia constricta

Prosopis standulusa

Sulanum eleagnifolium

Conyza conlleri

Euphotia denlose

.

*
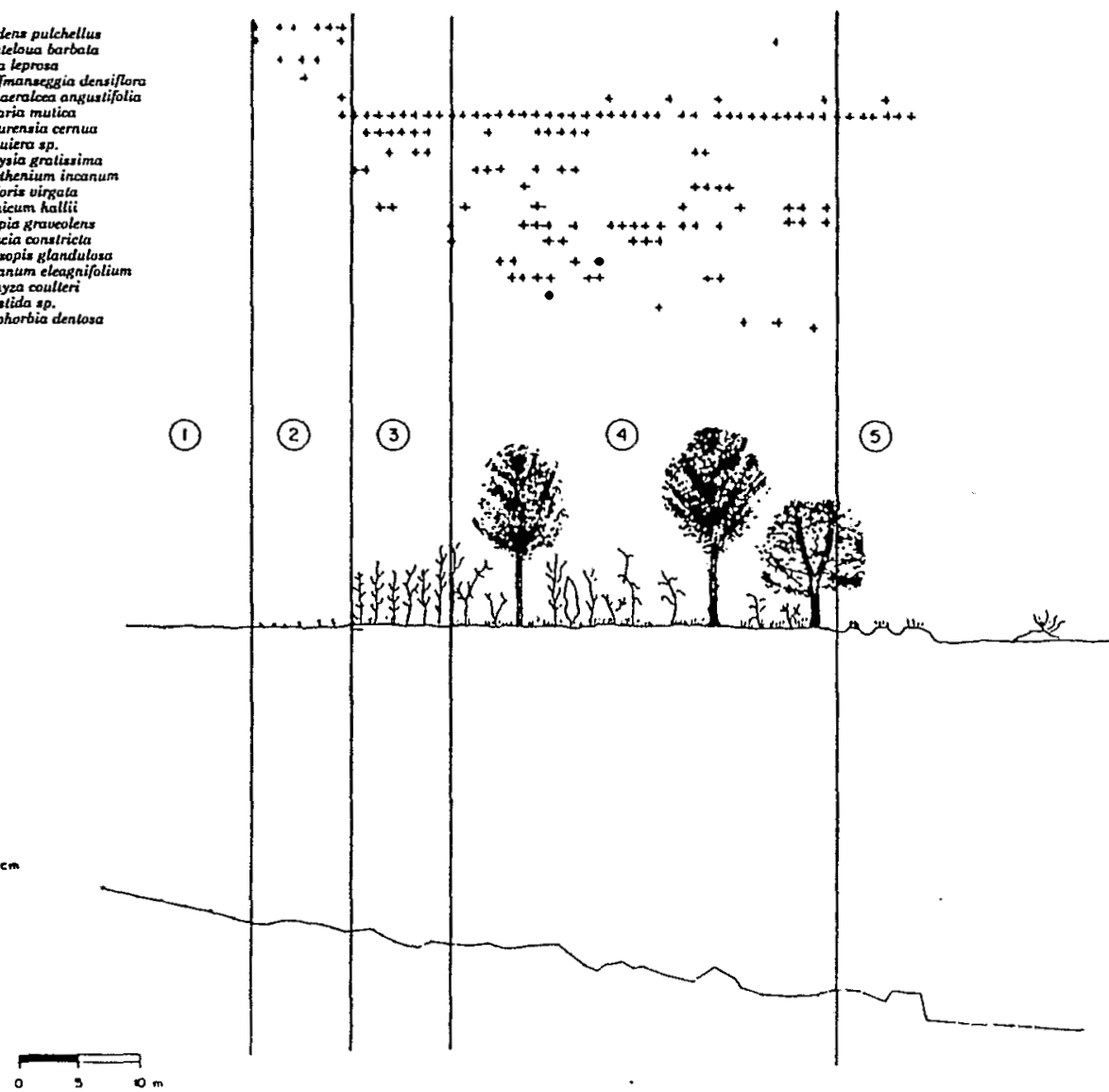

Figure 16.2. Section across a vegetation stripe showing plant species distribution (above) and the surface level profile (below). Zones are (1) Bare area, transit zone; (2) deposition area, pioneer zone; (3) screen of Flourensia cernua; (4) dense bushy area; (5) downhill bare area (after Cornet et al. 1988).

Our field observations at the limits between the matorral and the striped vegetation suggest that the phenomenon develops at present within the study area through a slow regressive evolution of the geomorphic forms and the drainage network. The regressive evolution of the channel network leads to their progressive attenuation on the lower slope, and to the replacement of a gully-type water flow to a sheet flow. The plants that were growing along the drainage axis (such as Hilaria mutica, Flourensia cernua and Prosopis glandulosa) build up into dense clumps, and the vegetation becomes structured so that it becomes an obstacle to runoff. This physical obstruction increases the water availability in this point and reduces it 
further down, preventing the matorral growth. The development of vegetation stripes seems a consequence of this evolution, linked with an initiation of sheet flow (Cornet et al. 1987, Mabbutt and Fanning 1987). Figure 16.1 shows the sequence of evolution of the landscape unit through time, according to the preceding hypothesis.

\section{Methods}

\section{Soil Water Budget}

Soil moisture was monitored using a transect parallel to the slope and across one vegetation stripe (Delhoume 1988). Access pipes for a neutron probe were installed in six different locations: one in the upslope bare ground; one in the border zone, almost flat, with a ground surface deposit of fine material, colonized by sparse, low vegetation, also called "pioneer zone"; three at different levels within the vegetation stripe; and one in the downslope bare zone (Fig. 16.2). The measurements were made from 1983 to 1986 , approximately every 10 days during the rainy season and every month in the dry season. In order to assess the intensity of the runoff, which could not be directly measured, determinations of soil moisture were repeatedly made before and after storms in order to know the infiltration amounts for each site.

The soil water storage was calculated, using the water content weight and the bulk density of dried soils. In fact, the soil is rich in clay, with dominant smectic clay which produces expansion or shrinkage of the soil, according to its water content. A study of similar soils (Delhoume 1988) has shown that, as a whole and considering all levels of moisture, the bulk density of the clay soils varies from 1.4 to 1.7 when the water weight varies from 30 to $5 \%$. Generally speaking, the water volume content is overestimated from the use of dry soil bulk density in calculations, and more so if the soil moisture is higher. However, although our values may not be absolute, our conclusions in terms of the functioning of the system are not affected.

The water balance in the soils was simulated for different situations along the toposequence, using a simplified version of the BIJOU model (Cornet 1981, Cornet and Rambal 1981). The purpose of the simulation is to relate punctual measurements with the continuous evolution of water balance and to calculate water availability and evapotranspiration of plant cover. This model is based on the following recurrent relation, which expresses the evolution of the water content in one soil layer:

$$
W_{j}=W S_{j-1}+R_{j}-L_{j}-D_{j}-A E T_{j}
$$


where $W S_{j}$ is a water content in a soil on day $j$

$R_{j}$ is the rainfall on the same day

$\mathrm{L}_{\mathrm{j}}$ and $\mathrm{D}_{\mathrm{j}}$ are the losses through runoff and drainage, respectively

$\mathrm{AET}_{\mathrm{j}}$ is a actual evapotranspiration on day $\mathrm{j}$

Evapotranspiration is calculated in the model from the experimental relation proposed by Eagleman (1971), which uses the potential evapotranspiration values, the vegetation cover, and the relative soil moisture. The lack of measurements does not allow a proper determination of the runoff in each site; considering the studies of Delhoume (1988), we assume that a rainfall below $4 \mathrm{~mm}$ does not produce any runoff. After the calculation of the AET value in each site, the $L$ value is determined by steps so that the calculated water storage matches the measured storage. Drainage below $120 \mathrm{~cm}$ was observed only once, in only one site, and drainage is considered as negligible except for that site.

\section{Vegetation Characteristics}

To investigate differences in vegetation change at a spatial scale related to the migration of the ecotone, we considered the same transect used for the installation of the aforementioned access pipes. Six interception lines (each $50 \mathrm{~m}$ long) were laid down perpendicular to the imaginary line that passes along the tubes, taking each tube as the median point. In each line, cover of the intercepted plant individuals was registered. Both the density of woody species and the height of all individuals were determined in rectangles of $50 \times 2 \mathrm{~m}$.

In order to assess the stability of the boundaries between one vegetation stripe and the bare areas, a grid of permanent quadrats was located at the upslope and the downslope boundaries of the vegetation stripe. In the upper limit, the grid consisted of 320 quadrats of $25 \times 25 \mathrm{~cm}$, arranged in a $10-\times 2-m$ rectangle, the main axis of which was perpendicular to the stripe front. In the lower limit, the grid consisted of 256 quadrats of the same dimensions, arranged in an 8- $\times 2-\mathrm{m}$ rectangle perpendicular to the stripe. The vegetation was sampled each year.

\section{Results}

\section{Soil Water Budget}

Table 16.1 shows the quantities of water stored in the soils during 5 characteristic rainy periods and for five positions in the toposequence. The moisture depth is always low for the bare zones, and water storage represents 10 to $27 \%$ of the rainfall. In the pioneer zone, it represents 60 to $150 \%$; in the upslope vegetation area or frontal zone, 170 to $530 \%$; and in 
Table 16.1 Determination of Water Storage in the Ground During 5 Characteristic Rain Events

\begin{tabular}{lccccc}
\hline Rain Event & 1 & 2 & 3 & 4 & 5 \\
Rainfall (R) (mm) & 37.7 & 33.3 & 7.5 & 24.7 & 6.0 \\
\hline A & & & & & \\
$\quad$ Moistured depth (cm) & 40 & 20 & 20 & 20 & 20 \\
$\quad$ Water storage (mm) & 6.6 & 7.1 & 2.0 & 2.6 & 0.9 \\
$\quad$ Water storage (\% of R) & 17.5 & 21.3 & 26.7 & 10.5 & 15 \\
B & & & & & \\
Moistured depth (cm) & 40 & 40 & 20 & 20 & 40 \\
Water storage (mm) & 23.2 & 23.2 & 6.3 & 15.1 & 9.5 \\
$\quad$ Water storage (\% of R) & 61.5 & 90.7 & 84 & 61.1 & 158.3 \\
C & & & & & \\
Moistured depth (cm) & 80 & 40 & 20 & 80 & 60 \\
$\quad$ Water storage (mm) & 81.7 & 60.0 & 13.2 & 66.6 & 31.8 \\
$\quad$ Water storage (\% of R) & 216.5 & 180.2 & 176 & 269.6 & 530 \\
E & & & & & \\
Moistured depth (cm) & 80 & 40 & 0 & 80 & 60 \\
$\quad$ Water storage (mm) & 62.2 & 53.9 & -1.1 & 51.8 & 10.7 \\
$\quad$ Water storage (\% of R) & 165 & 161.9 & & 209.7 & 178.3 \\
F & & & & & \\
$\quad$ Moistured depth (cm) & 40 & 20 & 0 & 20 & 20 \\
Water storage (mm) & 10.2 & 8.8 & 0.9 & 7.2 & 2.9 \\
Water storage (\% of R) & 27.1 & 26.4 & & 29.1 & 48.3 \\
\hline A & & & & & \\
\hline
\end{tabular}

$\mathrm{A}=$ upslope bare ground. $\mathrm{B}=$ pioneer zone. $\mathrm{C}=$ upslope part of the vegetation stripe. $E=$ downslope part of the vegetation strip. $F=$ downslope bare ground. $R=$ Rainfall of the rain event under consideration. Values above $100 \%$ indicate input from run off water.

the downslope vegetation area 160 to $210 \%$. Percentages higher than $100 \%$ indicate the contribution of runoff water in the water stock. The absence of measurements of rainfall intensities does not allow a correlation between the relative importances of runoff and rainfall water, but additional observations have shown that runoff occurs for showers over $4 \mathrm{~mm}$ (Delhoume 1988), the minimum value we have taken into account.

Figures 16.3A and 16.3B show the distribution of moisture below ground across the vegetation stripe. The situations in Figure 16.3A correspond to a rainy period in 1984 : June 26 , before any rain was recorded; July 7, after a 33.2-mm rain over a 3-day period; and July 14 , at the end of the subsequent dry week. Figure 16.3B corresponds to two measurements in 1985: March 6, which represents the peak of the dry season; and August 19 , which represents the situation after a $50.2-\mathrm{mm}$ rain 3 days before.

Figure 16.3 shows that the heterogeneity of the soil moisture distribution is twofold: (1) a horizontal discontinuity associated with the presence of the vegetation stripe, where the influence of the ecotone depends on its 
mechanical characteristics (an obstacle to water flow) and on its hydrodynamic properties (a higher permeability of the soil surface), and (2) a vertical discontinuity in soil texture around the $60-$ to $70-\mathrm{cm}$ depth, which slows the percolation toward deeper layers but does not cause a lateral displacement of soil water. This discontinuity corresponds to the transition from the original soil material with a finer texture of more than $40 \%$ clay to an allogenous topsoil made of coarser elements and with a clay content less than 15 to $30 \%$. It is to be noted that water percolates deeper just below the median part of the vegetation stripe, where taller trees are found.

Figure 16.4 shows the evolution from March to September 1984 of the soil moisture at depths between 0 and $120 \mathrm{~cm}$ in three zones: bare zone, the pioneer zone, and the upslope part of the vegetation stripe. The soil textural discontinuity can be noted in the bare and pioneer zones, but infiltration below the upslope vegetation goes deeper than the discontinuity and allows some water storage in lower levels. Thus, except for the superficial layer, the soil water content is always higher under the vegetated area.

Figure 16.5 shows the rainfall and the simulated evolution of the water storage during 1985 for the upper bare zone and the upslope part of the vegetation stripe. Table 16.2 shows the calculated amounts and the various components of the water budget for the same period. These data show clearly that the soil water storage in the vegetation stripe is higher than in the bare areas. The actual evapotranspiration is 1.8 to 3.0 times higher than the rainfall.

\section{Vegetation Characteristics}

Figure 16.6 shows the density, height, and cover of the three most abundant woody species, and the cover of Hilaria mutica. Zone A and F in Figure 16.6 correspond to the upslope and downslope bare areas, respec-

Table 16.2 Calculated Values of the Water Budget Components (in mm) during the Period February 8th to September 9th, 1985

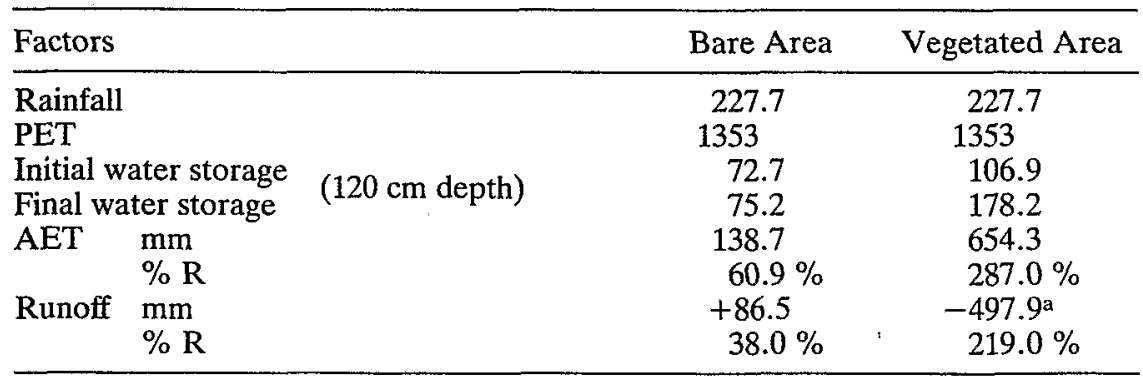

$\mathrm{PET}=$ potential evapotranspiration. $\mathrm{AET}=$ actual evapotranspiration. $\mathrm{R}=$ rainfall. andicates input from run-off minus losses through drainage. 


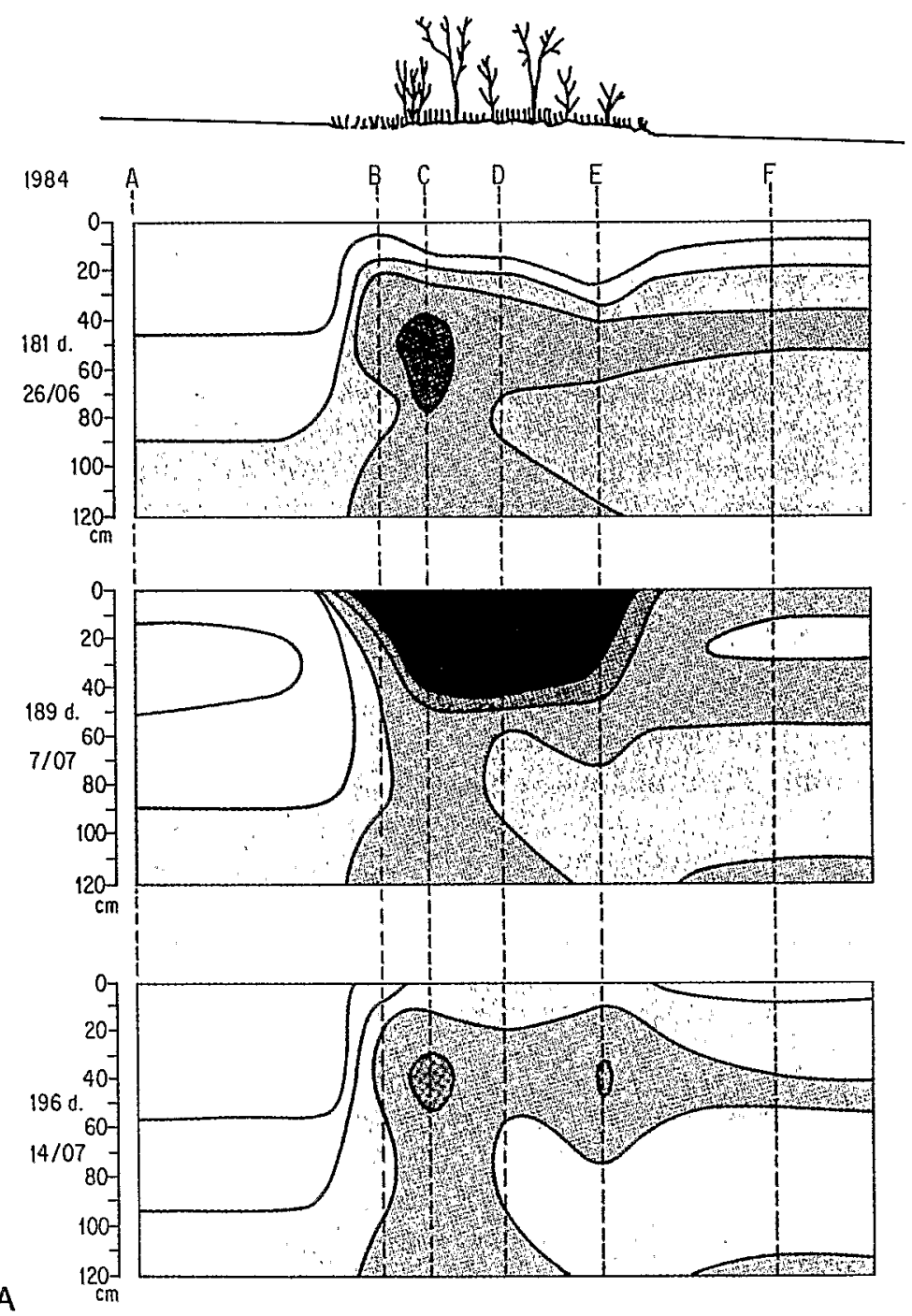

Figure 16.3. Isolines showing the distribution of soil moisture across the vegetation stripe. A through $\mathrm{F}$ indicate the locations of tube access for the neutron probe. In (A), the evolution of soil moisture is shown at three times (on June 16th before any rain was recorded; on July 7 th after a 33.2-mm rain over a 3-day period; on July 14th at the end of a subsequent dry week). In (B), soil moisture for two dates is presented (March 6th, showing the peak of dry season, and August 16th, showing a representative situation after a $50.2 \mathrm{~mm}$ rainfall). 


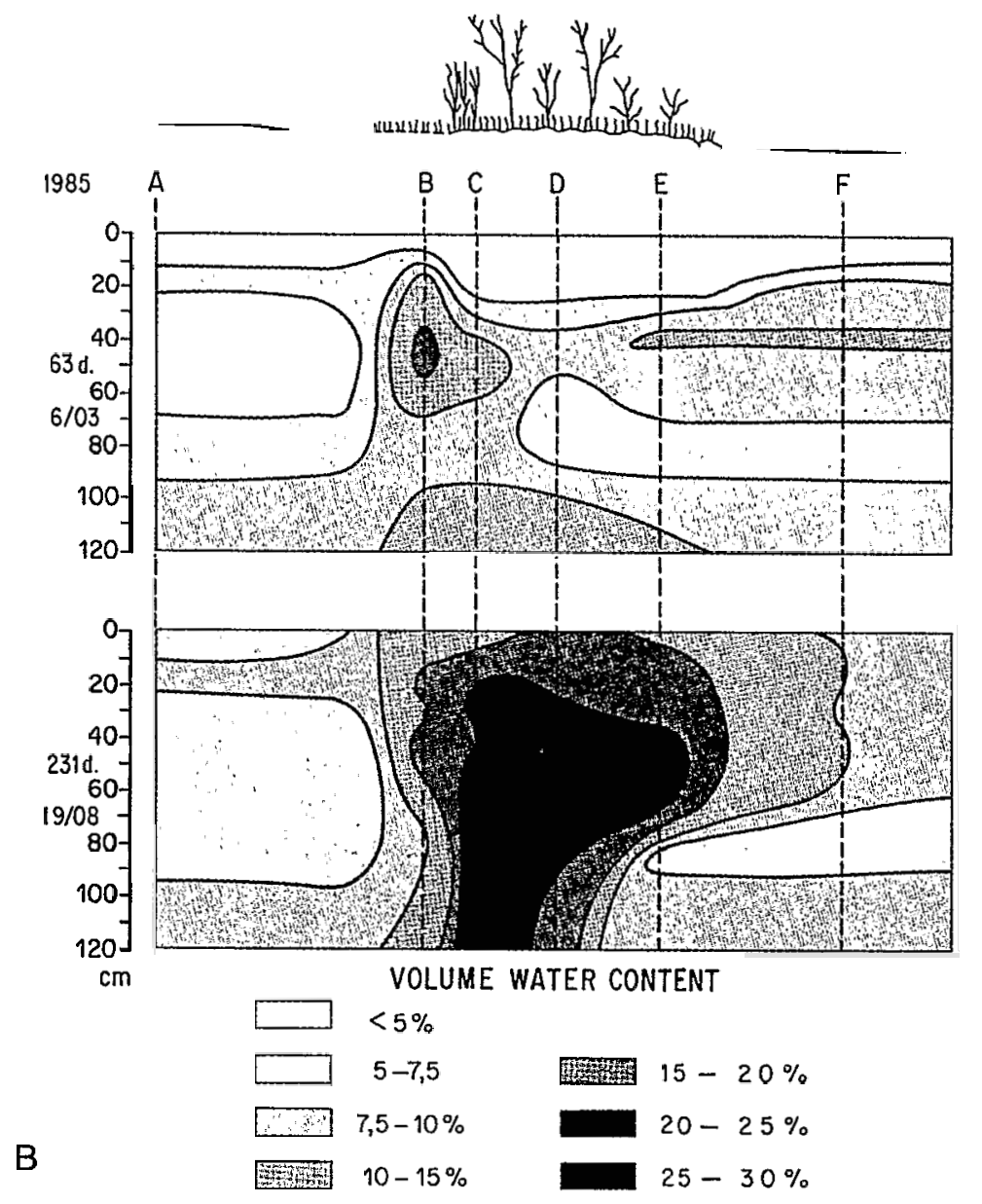

tively, and zones $\mathrm{B}$ through $\mathrm{E}$ correspond to the stripe from the pioneer zone to the back of the stripe. There are marked differences between the cover of Flourensia and that of Prosopis and Hilaria. Flourensia shows a high cover and density in the frontal part (zone C) and thins in the other zones, lowering its cover. Although Prosopis shows a relatively low density, its cover is higher in the central part of the stripe (zone D). Trees in this zone are also significantly taller, indicating a zone of high deep-water demand. Aloysia gratissima follows a tendency similar to Prosopis, but, as in Flourensia, the height is constant along the stripe. The cover of Hilaria is higher toward the central and back part of the vegetation stripe.

The results gathered in the grids of permanent quadrats showed no obvious regression of vegetation cover in the lower grid. Only a few gaps in the Hilaria mutica cover due to the death of isolated tufts were observed. 


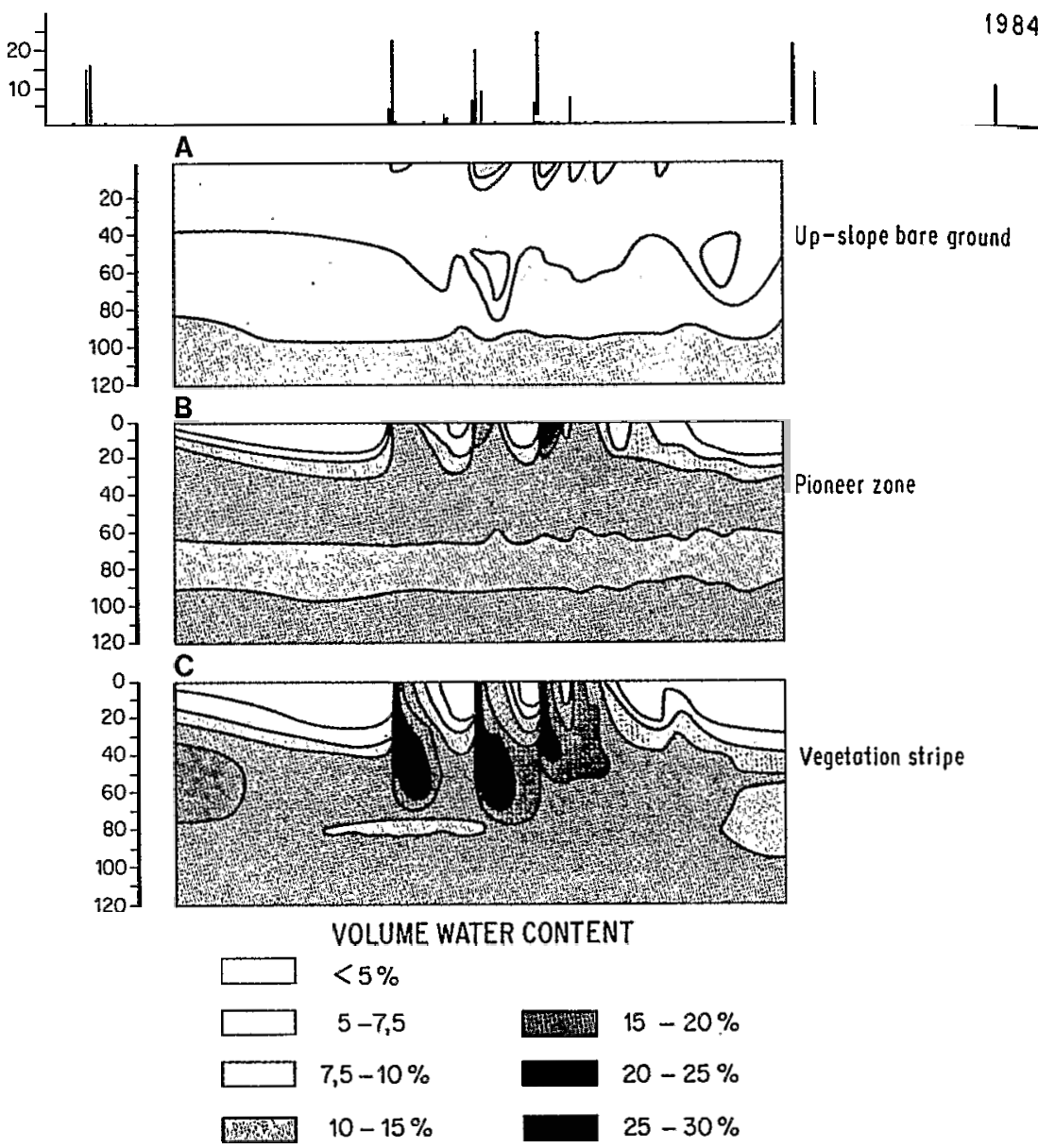

Figure 16.4. Evolution from March to September of 1984 of the soil moisture at different depths for (A) upper bare zone, (B) pioneer zone, and (C) upslope part of the vegetation stripe.

On the contrary, in the upper grid, clear evidences of vegetation colonization were obtained. Figure 16.7 shows the mean number of quadrats occupied by species of the following groups: (A) saplings of woody species, (B) perennial grasses, and (C) other herbaceous perennials. Annuals and geophytes were not considered, due to the variability of their occurrence related to rainfall.conditions. Tridens pulchellus was not included with perennial grasses for two reasons: (1) it is a colonizer species that never appears inside the arc, as opposed to the other perennial grasses, and (2) it 


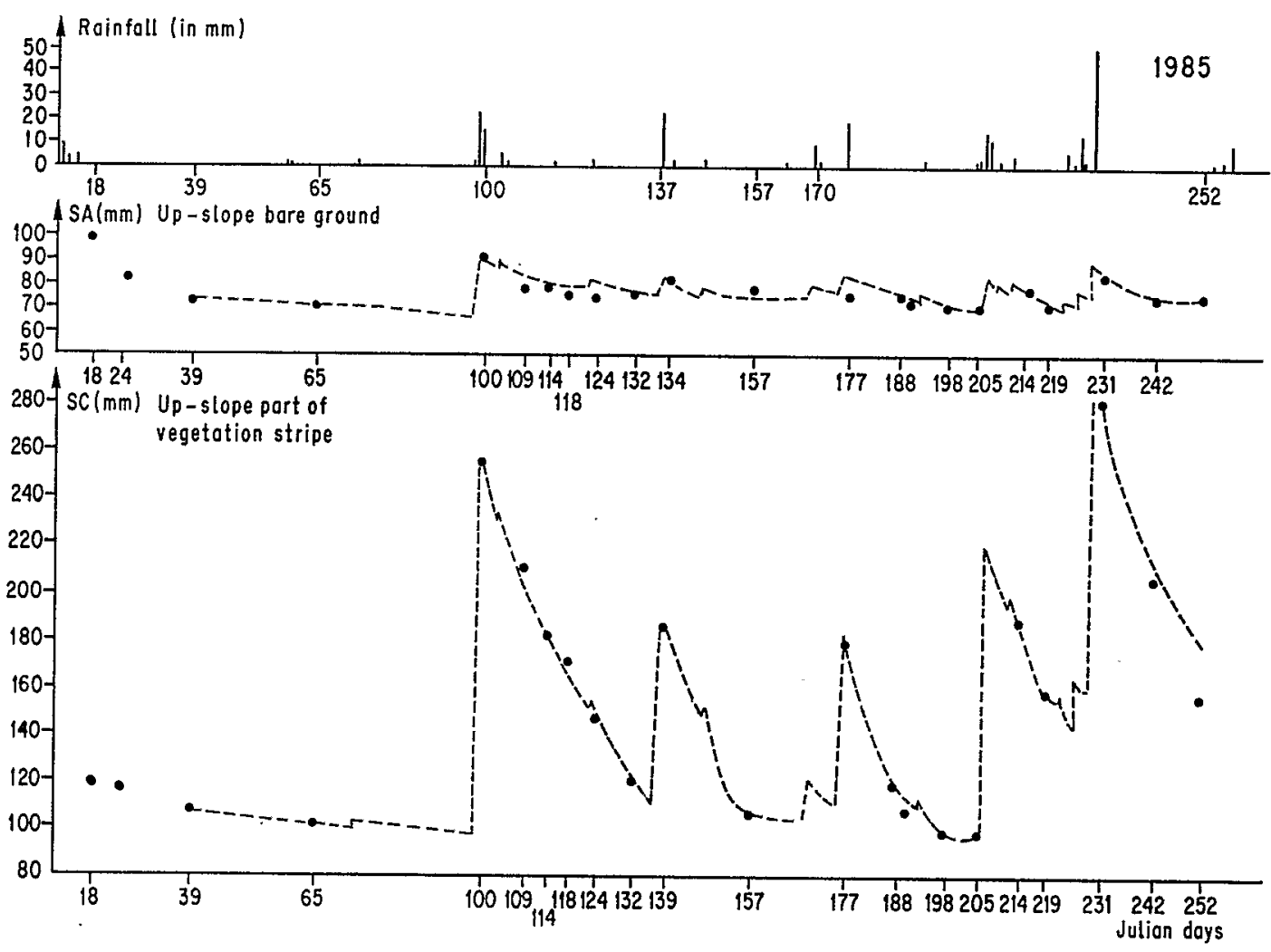

Figure 16.5. Rainfall and simulated evolution of the water storage. Data of the year 1985 for the upslope bare ground and the upslope portion of the vegetation stripe. The dots correspond to the measured amounts of stored water. 

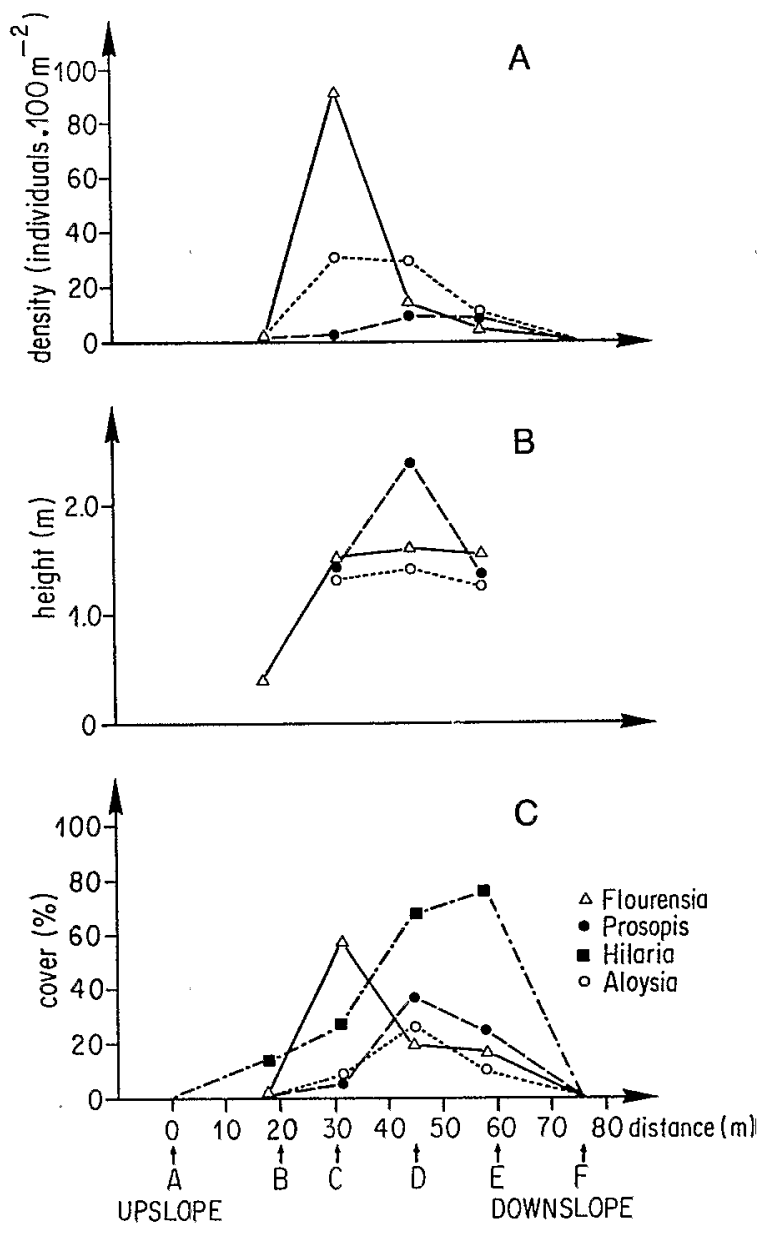

Figure 16.6. Density (A), height (B), and cover (C) of the most abundant woody species within a vegetation stripe. Letters below the arrows indicate the position of the tube access for the neutron probe, as in Figures 16.3A and 16.3B.

is the most frequent species (values of $72.8,78.8$, and $78.8 \%$ of plots where species occurred for 1982, 1984, and 1986, respectively), and its inclusion would have increased artificially the variance of the group. The increase of perennial grasses and of saplings of woody species indicates the slow establishment of the species that dominate in the arc. In fact, the frequency values of Hilaria mutica, the dominant grass in the arc, were 3, 5, and 25 for 1982, 1984, and 1986, respectively. The frequencies of Prosopis glandulosa were 0,5, and 6, respectively. The frequencies of Flourensia cernua showed a slight decrease, probably related to seedling mortality; the dis- 


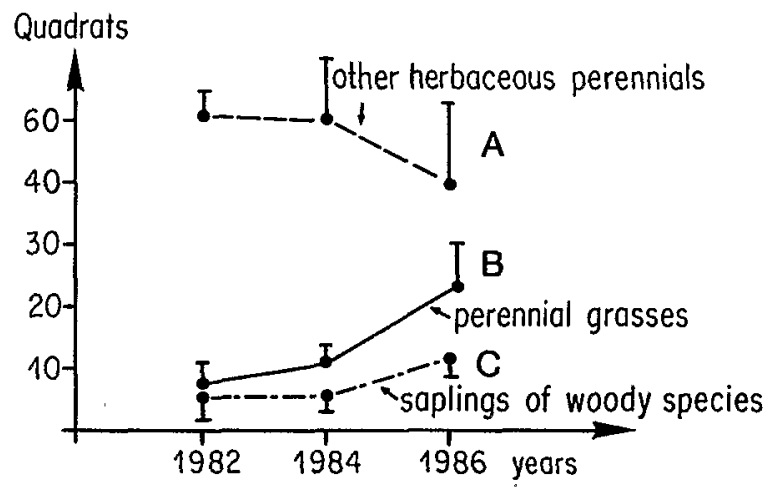

Figure 16.7. Changes in occurrence (on 320 permanent quadrats) through time of (A) saplings of woody species, (B) perennial grasses, and (C) other herbaceous perennials. Data are from the pioneer zone in the front of the arc. The means (and one standard error) of the quadrats occupied by the species of each group are shown.

tribution of seedling of this species is very aggregated, and seedling mortality proceeded as the dominant individuals recorded in 1986 developed.

The group of other herbaceous perennials includes low pioneer species, which, together with Tridens pulchellus and annual species, colonize the bare area as water becomes available. Their frequencies are higher in the frontal part of the grid and lower in the distal part, where they are gradually replaced by species coming from the stripe, such as tufted perennial grasses (Hilaria mutica, Trichloris crinita) and shrub seedlings (Prosopis glandulosa, Flourensia cernua). The result, consequently, is an upslope migration of the pioneer zone and the upper part of the stripe, related to the inflow of rain water and a colonization of the fringe, which benefits from water inflow and sedimentation. The advance is made by plants that improve the soil properties and enable the establishment of more demanding species.

\section{Discussion}

The data on soil water dynamics coupled with those on vegetation dynamics show that both are functionally related, resulting in a dynamic equilibrium between vegetation structure and redistribution of rain water through sheet flow.

Infiltration in the bare zones reaches only the upper $20 \mathrm{~cm}$ in the soil and practically no water storage is obtained. In the pioneer zone, due to the presence of vegetation, water infiltrates to at least a depth of $40 \mathrm{~cm}$. Therefore, the duration of the water stock is longer and favors the growth of a 
sparse plant cover. Within the vegetated area where woody species are frequent, water percolates deeper; depending on the intensity and frequency of rainy events, water can penetrate to depths lower than $60 \mathrm{~cm}$, where the texture discontinuity between the parent and allochthonous material is found. Root density and evaporation in the top soil leads to fast drying of the top layers, but deeper layers remain wet for longer periods.

The evolution of the water budget in the different zones of the stripe can be explained by the presence or absence of the vegetation itself. In the bare zone, a superficial and impermeable crust prevents water percolation, which circulates as sheet flow. Due to the presence of woody plants and tussocks of perennial grasses, the frontal part of the vegetation stripe acts as a small dam. Consequently, water is slowed down as it passes through the pioneer zone and percolates deeper as it reaches the central part of the stripe. This water carries sediments, which are deposited in the frontal part. The availability of water and the better substrate represented by the newly deposited sediments facilitate the establishment of pioneer species in the fringe of the bare area. The production of roots and the buildup of organic matter gradually improve soil porosity and percolation so that, in turn, pioneer species are replaced by tussock grasses and woody species, as the colonization process advances over the bare area.

In the arc itself, infiltration is maximal, and the cover of woody species and tussock grasses is high. In this zone, the evapotranspiration is 1.8 to 3.0 times higher than the rainfall. Moreover, in this zone, vegetation cover reduces losses through soil evaporation, and consequently, the ratio of evapotranspiration to water supply is maximized (i.e., most of the water passes through the plants to the atmosphere). This zone also shows the highest content of water at depths below $60 \mathrm{~cm}$ and to more than $120 \mathrm{~cm}$, which suggests that water may penetrate deeper. Thus, in the absence of a completely impermeable soil layer, there is no important lateral flow below the vegetation stripe.

To the back of the stripe, the cover, height, and density of woody species decrease, whereas the cover of tussock grasses increases. Evapotranspiration remains fairly constant, at 1.6 to 2.1 times the rainfall, and the water storage below $60 \mathrm{~cm}$ is less important than in the central part.

At the limit between the arc and the bare area, runin water arrives only exceptionally, and the corresponding vegetation can then only use amounts of water that are equal to or hardly more than the local rainfall, and plant cover decreases consequently, especially during periods of drier years. How long these periods need to be in order to produce a significant regression of the arc vegetation in our study site remains unknown, but observations in northern Burkina Faso (Toutain and De Wispelaere 1979) showed that the ecosystem remained remarkably stable when not overexploited, in spite of drought over the preceding 15 years.

The plant community studied in the Mapimi Biosphere Reserve is simi- 
lar to vegetation reported from Africa or Australia, which have similar climatic, geomorphological, and edaphic characteristics. This vegetation pattern apparently derives from the geological evolution and from the runoff in the arid or semiarid zones on soils with a lower permeability. Geomorphic processes create patches both directly and indirectly, through the flux of material and resources that are of biological significance, and these may determine the location and persistence of vegetative communities and ecotones. The response of abiotic and biotic factors to various geomorphic controls on ecotones is different, depending on landscape and energy of flows. As is noticed by Swanson and et al. (Chapter 15, this volume) "Geomorphic processes operating at low energy levels, such as sheet flow in arid regions, control the horizontal redistribution of resources, creating patterns with boundaries oriented normal to primary flows paths."

In a fir woodland of New-Hampshire, Sprugel (1976) described the dynamics of vegetation communities structured along parallel stripes. In a way similar to what is studied here, one observes that the plant cover is restructured perpendicular to the acting parameter, which is runoff at Mapimi and the dominant wind direction in the fir forests. In both locations, the community is stable at the scale of the overall unit, a steady-state ecosystem, whereas the vegetation stripes show permanent changes. The changes are materialized by ecotones, which move with a constant orientation across the landscape. The ecotone dynamic is a reaction of the ecosystem to an oriented, predictable, although irregular disturbance.

\section{References}

Boaler SB, Hodge CAH (1964) Observations on vegetation arcs in the northern region, Somali Republic. J of Ecol 52:511-544

Boudet G (1972) Désertification de l'Afrique tropicale sèche. Adansonia ser. 2,12, 4:505-524

Breimer R (1987) Physiographic soil survey. In Montana C (ed) Estudio integrado de los Recursos Vegetacion, Suelós y Agua en la Reserva de la Biosfera de Mapimi. Vol. 1. Ambiente natural y Humano. Instituto de Ecología, Mexico, DF, Mexico, 115-134

Brown DE (1982) Chihuahuan desert scrub. In Brown DE (ed) Biotic Comunities of American southwest United States and Mexico. Desert Plants 4(1-4): 169179

Cornet A (1981) Le bilan hydrique et son rôle dans la production de la strate herbacée de quelques phytocénoses sahéliennes au Sénégal. Thèse Doc. Ing. USTL Montpellier, France

Cornet A (1987) Principales caractéristiques climatiques de la Réserve de la Biosphère de Mapimi. In Montana C (ed) Estudio Integrado dé los Recursos Vegetación, Suelos y Agua en la Reserva de la Biosfera de Mapimi. Vol. I. Ambiente Natural y Humano. Instituto de Ecología, Mexico City, pp 45-76

Cornet A, Delhoume JP, Montana C (1987) Vegetation Patterns and Soils in the Mapimi Bolson (Chihuahuan Desert, Mexico ). Vol. 1. Vegetation Arcs- 
Contributed Papers of the Second Symposium on Resources of the Chihuahuan Desert Region, Alpine, Texas, Oct 20-23 1983. Series of the CDRI, 13, 18p

Cornet A, Delhoume JP, Montana C (1988) Dynamics of striped vegetation patterns and water balance in the Chihuahuan Desert. In During HJ, Werger MJA, Willems JH, (ed) Diversity and Pattern in Plant Communities, SPB Academic Publishing, The Hague, The Netherlands, pp 221-231

Cornet A, Rambal S (1981) Simulation de l'utilisation de l'eau par une phytocénose de la zone sahélienne au Sénégal. Test de deux modèles. Actes du colloque Informatique et Biosphère, Paris, 156-179

Delhoume JP (1987) Distribution spatiale des sols le long d'une toposeguence représentative de la Réserve de la Biosphère de Mapimi. In Montana C (ed) Estudio Integrado de los Recursos Vegetacion, Suelos y Agua en la Reserva de la Biosfera de Mapimi. Vol. 1. Ambiente Natural y Humano. Instituto de Ecologia, Mexico City, pp 135-167

Delhoume JP (1988) Contribution à l'Étude des Relations Eau sol Végétation en Zone Aride du Nord du Mexique. Rapport Scientifique. ATP PIREN CNRS, ORSTOM, INRA, CIRAD. 38p

Di Castri F, Hansen AJ, and Holland MM (1988) A new look at ecotones. Biol Intl (special issue No 17), IUBS Paris 163p

Eagleman JR (1971) An experimentally derived model for actual evapotranspiration. Agric Meteorol 8:385-394

FAO/UNESCO (1974) Soils Map of the World, $1 / 5000000$ (Vol. 1). Legende UNESCO, Paris, 59p

Greig-Smith P (1979) Pattern in vegetation: presidential address to the British Ecological Society. J of Ecol 67:755-779

Hemming CF (1965) Vegetation arcs in Somaliland. J of Ecol 53:57-68

Leprun JC (1979) Etude de l'évolution d'un système d'exploitation sahélien au Mali: Volet pédologique. A.C.C., Lutte contre l'aridité en milieu tropical. ORSTOM/ DGRST Rapp, Paris, 27p

Litchfield WD, Mabbutt JA (1962) Hardpan soil of semiarid western Australia. J of Soil Sci 13:148-159

Mabbutt JA, Fanning PC (1987) Vegetation banding in arid western Australia. J Arid Environ 12:41-59

Montana C (1987) La vegetación y sus relaciones con el ambiente. In Montana C (ed) Estudio Integrado de los Recursos Vegetacion, Suelos y Agua en la Reserva de la Biosfera de Mapimi. Vol. 1. Ambiente Natural y Humano. Instituto de Ecologia, Mexico City, pp 199-224

Montana C, Breimer R (1987) Major vegetation and environment units. In Montana C (ed) Estudio Integrado de los Recursos Vegetacion, Suelos y Agua en la Reserva de la Biosfera de Mapimi. Vol. 1 . Ambiente Natural y Humano. Instituto de Ecología, Mexico, City, pp 99-114

Rzedowski J (ed) (1981) Vegetación de Mexico. Limusa, Mexico, 432p

Schmidt RH, Jr. (1979) A climate delineation of the real Chihuahuan Desert. J Arid Environ 2:243-250

Slatyer RO (1961) Methodology of a water balance study conducted on a desert woodland community in central Australia. UNESCO, Arid zone research, 16, Plant-water relationships in arid and semi-arid conditions. Proceeding of MADRID Symposium, pp 15-26

Sprugel DG (1976) Dynamic structure of wave-regenerated Abies balsamea forests in the north-eastern United States. J of Ecol 64:889-910

Toutain B, De Wispelaere G (1979) Etude de l'évolution des paysages pastoraux du nord de la Haute-Volta. In Paturages de l'ORD du Sahel et de la zone de 
délestage au nord-est de Fada N'Gourma. Etudes Agropastorales No51 T.III, I.E.M.V.T. MAISON-ALFORT.

White LP (1970) "Brousse tigrée" patterns in southern Niger. J of Ecol 58:549-553 White LP (1971) Vegetation stripes on sheet wash surfaces. J of Ecol 59:615-622

Wickens GE, Collier FW (1971) Some vegetation patterns in the Republic of Sudan. Geoderma, 6:43-59

Worral GA (1959) The Butana grass patterns. J Soil Sci 10:34-53 


\section{Andrew J. Hansen Francesco di Castri}

Editors

\section{Landscape Boundaries \\ Consequences for Biotic Diversity and Ecological Flows}

\section{Contributors}

A.D. Armand A.F. Cornet V. Dale M. Debussche H.R. Delcourt P.A. Delcourt J.P. Delhoume R.L. De Velice R.T.T. Forman R.H. Gardner J.R. Gosz

G.E. Grant B.P. Hayden C.A. Johnston G.A. King M. Kuppers J. Lenihan J. Lepart J. Lopez-Portillo

B. Marks G. Merriam C. Montana P.N. Moore R.P. Neilson I.R. Noble R.V. O'Neill J. Pastor G. Pinay G.C. Ray P. Risser J. Rusek L. Ryszkowski R.O. Slatyer F.J. Swanson M.G. Turner D. Urban J. Wegner

D.A. Weinstein J.A. Wiens S.M. Wondzell

With 113 Illustrations

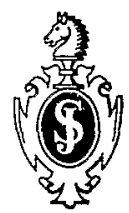

Springer-Verlag

New York Berlin Heidelberg London Paris

Tokyo Hong Kong Barcelona Budapest

ORSTIOM Fonds Documentaire $N^{\circ}: 37.667$ ex 1 


\section{Ecological Studies}

Analysis and Synthesis

Edited by

W.D. Billings, Durham (USA) F. Golley, Athens (USA)

O.L. Lange, Würzburg (FRG) J.S. Olson, Oak Ridge (USA)

H. Remmert, Marburg (FRG) 